УДК 539.3

Е. Л. Гарт, д-р фріз.-мат. наук,

В. С. Гудрамович, чл.-кор. НАН України, д-р техн. наук, О. А. Марченко

\title{
ВПЛИВ КІЛЬЦЕВОГО ВКЛЮЧЕННЯ НА НАПРУЖЕНО-ДЕФОРМОВАНИЙ СТАН СФЕРИЧНОЇ ОБОЛОНКИ 3 КРУГОВИМ ОТВОРОМ ПРИ ДIÏ РІВНОМІРНОГО ВНУТРІШНЬОГО ТИСКУ
}

Проведено комп'ютерне моделювання напружено-деформованого стану тонкостінної сферичної оболонки з круговим отвором, підкріпленим кільцевим включенням 3 іншого матеріалу, яка знаходиться під дією рівномірного внутрішнього тиску. Досліджено вплив геометричних та механічних параметрів включень на процес деформування оболонки.

Ключеві слова: сферична оболонка, круговий отвір, кільцеві включення, внутрішній тиск, напружено-деформований стан, коефріцієнт концентрації напружень, метод скінченних елементів.

Вступ. Тонкостінні просторові конструкції, елементами яких $\epsilon$ оболонки, знаходять широке застосування в різноманітних галузях техніки, промисловості, енергетиці та ін., що пов'язано з поєднанням в них таких властивостей як відносна легкість і висока міцність [1-4, 12, 22, 23]. За різних конструктивних або технологічних міркувань в оболонках часто створюють отвори і прорізи, які $\epsilon$ локальними концентраторами напружень, і можуть несприятливо впливати на процес експлуатації конструкції, призвести до ії̈ передчасного виходу з ладу $[9,10,17]$.

Оболонки, що застосовуються в реальних конструкціях, в більшості випадків мають традиційно прості геометричні фооми поверхонь (оболонки обертання). Складні конструкції $€$ зазвичай комбінацією вказаних форм оболонок. Врахування впливу локальних концентраторів на напружено-деформований стан (НДС) оболонки і способи зниження концентрації напружень в тонкостінних оболонках обертання $\epsilon$ актуальним завданням механіки деформованого твердого тіла.

Одним із варіантів вирішення цього питання $є$ застосування підкріплень або включень навколо отворів, різних геометричних форм і механічних властивостей [5-7, 19]. Це, у свою чергу, призводить до підвищення складності математичної моделі задачі, отримання розв'язку якої аналітичними методами у більшості випадків доволі складно, а іноді навіть неможливо. Тому при досліджені НДС конструкцій 3 неоднорідностями (отворами, включеннями тощо) доцільно 
використовувати числові методи механіки, які, на відміну від аналітичних, $€$ досить універсальними. До найбільш ефективних відносять сіткові методи: метод скінченних елементів [14, 15, 24], метод скінченних різниць тощо, та їх проекційно-ітераційні схеми реалізації [20, 21], які дозволяють прискорити збіжність процесу отримання розв'язку задачі та суттєво зменшити витрати комп'ютерного часу розрахунків.

Питанню визначення НДС тонкостінних оболонок обертання присвячено багато публікацій. Так, в [18] досліджено розподіл напружень у сферичному днищі, яке ослаблене малим центрально розташованим круговим отвором, при вісесиметричному навантажені за припущенням, що контур отвору навантажений перерізуючим зусиллям. У [11] визначено НДС сферичної оболонки як куполу з одним жорстко закріпленим краєм та довільно розташованим непідкріпленим круговим отвором. У [16] здійснено аналіз напруженого стану ізотропної сферичної оболонки з круговим отвором, край якого підкріплений широким пружним кільцем. Фундаментальні результати з дослідження розподілу напружень в пластинах і оболонках біля різноманітних отворів отримані Г. М. Савіним і наведені у його монографії [13]. Зокрема, подано приклади розподілу напружень у сферичній оболонці з круговим, еліптичним, трикутним та квадратним отворами з заокругленими кутами. Отримані розв'язки у випадку підкріплених кругового та еліптичного отворів тонким пружним кільцем.

У [8] досліджено вплив підкріплення у вигляді широкого пружного кільця та за дії температурного поля на оболонку з отвором; наведені аналітичні розв'язки для випадків різних форм отворів.

У даній роботі проведено комп'ютерне моделювання поведінки тонкостінної сферичної оболонки 3 круговим отвором і кільцевим включенням та здійснено скінченно-елементний аналіз впливу геометричних та механічних параметрів підкріплюючих елементів отвору, які моделюються включеннями із матеріалу, відмінного від матеріалу оболонки, на її НДС в місцях локальних концентраторів.

Постановка задачі. Розглянемо пружну тонкостінну ізотропну сореричну оболонку радіусу $R$, товщини $h$ з круговим отвором радіусу $r$, що підкріплюється кільцевим включенням 3 іншого, ніж основний матеріал оболонки, матеріалу ( $h_{1}-$ ширина включення). Вважається, що підкріплюючі елементи змодельовані вставками товщини $h$, що відповідає товщині оболонки; на границях включень задані умови жорсткого зчеплення.

Оболонка знаходиться під дією рівномірного внутрішнього тиску інтенсивності $p=$ const (рис. 1).

Необхідно визначити НДС оболонки з отвором, дослідити вплив ширини і механічних властивостей кільцевих підкріплень на її НДС в зонах концентрації напружень, провести порівняльний аналіз одержаних результатів з результатами для оболонки без включень, виявити умови можливого зменшення ії̈ параметрів НДС при відповідному розташуванні і сполученні геометричних та механічних характеристик включень. 


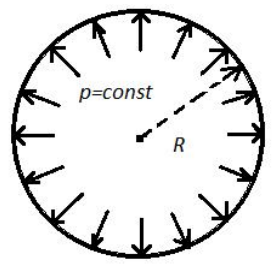

a)

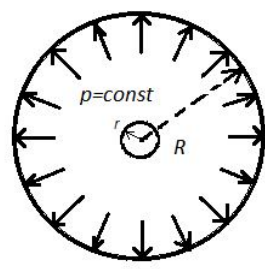

б)

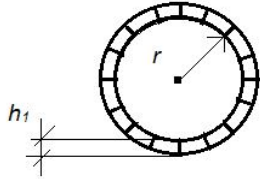

B)

Рис. 1 - Геометрія та схема навантаження сферичної оболонки:

а) без отвору; б) з круговим отвором;

в) 3 круговим отвором і кільцевим включенням

Зазначимо, що при використанні даної оболонки як елементу конструкції, що знаходиться під дією внутрішнього тиску, слід мати на увазі необхідність наявності накривки, що забезпечує її герметичність. В цьому випадку виникають деякі особливості розрахунку (крайові ефекти, пов'язані з особливостями кріплення накривки, можливість наявності фрланцевого з'єднання, що часто $€$ технічно необхідним при наявності накривок для реальних конструкцій техніки та ін.).

Числовий аналіз. Розрахунки проведені на персональному комп'ютері з тактовою частотою Intel囚 Core $^{\text {TM }}$ i5-4460 CPU @ 3,20 GHz, оперативною пам'яттю $8 \mathrm{~GB}$, розрядністю системи х64 при використанні пакету МCE-аналізу. Кількість скінченних елементів - 56562, вузлів -11054.

Результати отримані для сфреричної оболонки з такими параметрами: $R=2 M, h=0,001 R, r=0,05 R$. Ширина кільцевого включення $h_{1}=0,005 R$. Для визначеності в розрахунках застосовано два види матеріалу 3 такими модулями пружності $E$ та коефіцієнтами Пуассона $v$ : $E_{1}=110$ ГПа, $v_{1}=0,32, E_{2}=210$ ГПа, $v_{2}=0,3$ з відповідними їм границею міцності та умовною границею текучості: $\sigma_{s}=400 \mathrm{MПа,} \sigma_{0,2}=280 \mathrm{MПа}$, $\sigma_{в}=630 \mathrm{MПа,} \sigma_{0,2}=375 \mathrm{MПа} \mathrm{[3].} \mathrm{Вибір} \mathrm{матеріалів} \mathrm{носить} \mathrm{умовний}$ характер. Внутрішній тиск $p=0,1 \mathrm{MПа.}$

У результаті проведеного комп'ютерного моделювання та обчислювальних експериментів на основі скінченно-елементного аналізу встановлено вплив радіусу $r$ кругового отвору на НДС оболонки. Для цього було змодельовано п'ять оболонок з різними розмірами отвору: $r=0,1 R ; 0,2 R ; 0,3 R ; 0,4 R ; 0,5 R$. Аналізуючи отримані розв'язки (рис. 2), прийшли до наступних висновків:

- концентрація напружень зосереджена на контурі кругового отвору, розподіляється вздовж нього рівномірно; інтенсивність напружень поступово зменшується від контуру отвору вздовж меридіана в бік периферії оболонки;

- для різних значень радіусу $r$ отвору існує зона переходу від максимального значення інтенсивності напружень до номінального, розміри цієї зони прямо пропорційні величіні радіусу отвору;

- величина коефіцієнта концентрації напружень не залежить від величини радіусу отвору. 


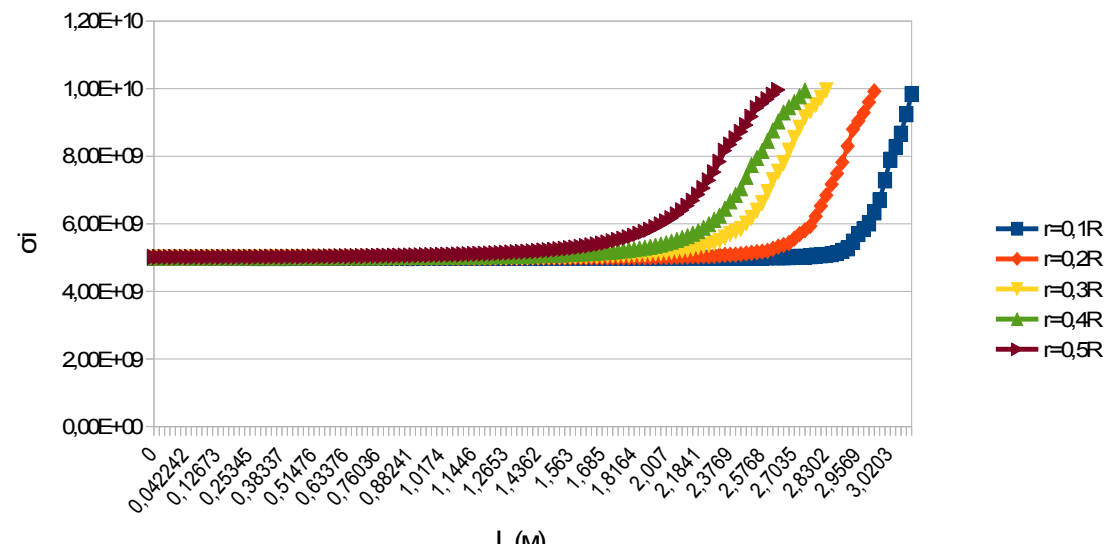

Рис. 2 - Розподіл інтенсивності напружень $\sigma_{i}($ Па) уздовж меридіана сореричної оболонки 3 круговим отвором

Значення коефріцієнта концентрації напружень для сфреричної оболонки, що знаходиться під рівномірним внутрішнім тиском, наведено в [13].

Залежність зміни величини зони поступового переходу інтенсивності напружень від максимального значення до номінального вздовж меридіана оболонки від радіусу отвору зведено у табл. 1. Тут введено позначення: $L^{*}$ - довжина зони переходу вздовж меридіана; $L-$ довжина 1/4 меридіана оболонки; I - довжина частини меридіана, вздовж якої спостерігається номінальне напруження.

Таблиця 1 - Величина довжини $L^{*}$ зони переходу від максимального значення $\sigma_{i}$ до номінального вздовж меридіана оболонки в залежності від радіусу $r$ отвору

\begin{tabular}{|c|c|c|c|c|c|}
\hline$r$ & $0,1 R$ & $0,2 R$ & $0,3 R$ & $0,4 R$ & $0,5 R$ \\
\hline$L$ & $1,52 R$ & $1,49 R$ & $1,41 R$ & $1,37 R$ & $1,32 R$ \\
\hline$I$ & $1,38 R$ & $1,12 R$ & $0,82 R$ & $0,61 R$ & $0,31 R$ \\
\hline$L^{*}$ & $0,14 R$ & $0,37 R$ & $0,59 R$ & $0,76 R$ & $1,01 R$ \\
\hline
\end{tabular}

3 табл. 1 випливає, що збільшення радіусу зони переходу від максимального значення $\sigma_{i}$ до номінального $€$ прямо пропорційним збільшенню розміру $r$ отвору з похибкою $\sim 3 \% \div 5 \%$.

Введемо коефіцієнт відносної жорсткості включення за фрормулою:

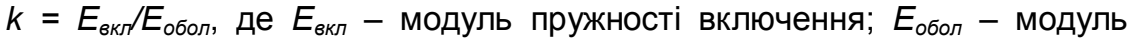
пружності оболонки. Розглянемо випадки, коли $k>1$ (більш «жорстке» включення) і $k<1$ (більш «м'яке» включення). 
Спочатку розглянемо модельну задачу для сферичної оболонки 3 круговим отвором, контур якого підкріплений тонким пружним кільцем, що має квадратний поперечний переріз [13].

На рис. 3 та рис. 4 наведено розподіл інтенсивностей деформацій $\varepsilon_{i}$ і напружень $\sigma_{i}$ відповідно вздовж меридіана ссреричної оболонки у випадку «м'якого» тонкого $\left(h_{1}=0,1 r\right)$ кільцевого включення $(k<1)$.

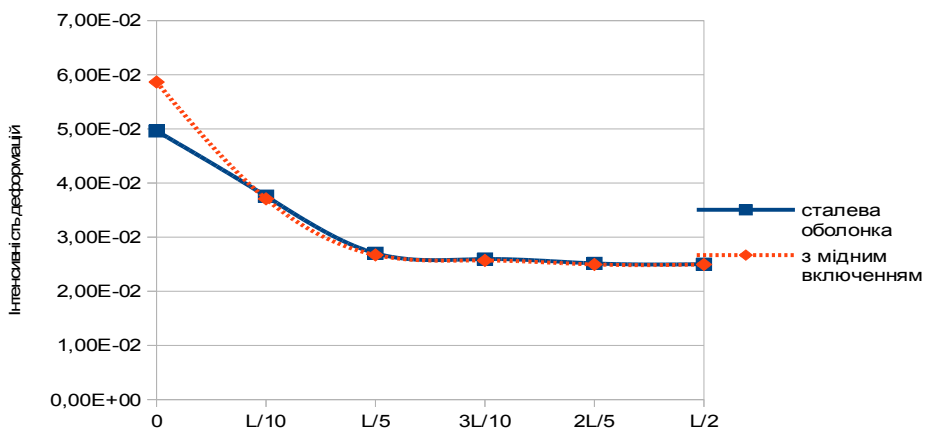

Рис. 3 - Розподіл інтенсивності деформацій $\varepsilon_{i}$ вздовж меридіана оболонки

3 круговим отвором та тонким кільцевим включенням при $k<1$

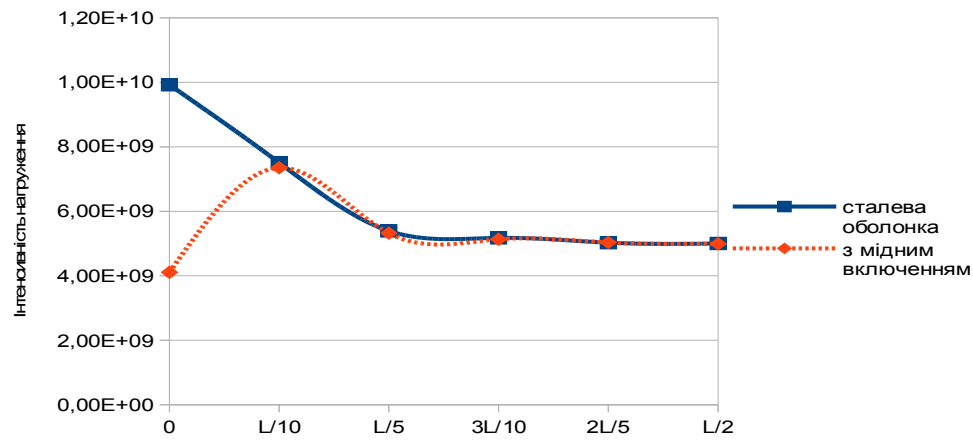

Рис. 4 - Розподіл інтенсивності напружень $\sigma_{i}($ Па) вздовж меридіана оболонки 3 круговим отвором та тонким кільцевим включенням при $k<1$

При застосуванні більш «м'якого», ніж основний матеріал оболонки, тонкого кільцевого включення інтенсивність напружень зменшується в 2,5 разів у порівнянні з оболонкою без включення, але, у той же час, інтенсивність деформацій збільшується на 20\%.

На рис. 5 та рис. 6 подано розподіл інтенсивностей деформацій і напружень відповідно вздовж меридіана сферичної оболонки у випадку «жорсткого» включення (k>1). 3 графріків видно, що при застосуванні більш «жорсткого», ніж основний матеріал оболонки, тонкого включення інтенсивність напружень збільшується в $\sim 2$ рази у порівнянні 3 оболонкою без включення; інтенсивність деформацій при цьому зменшується на $\sim 25 \%$. 


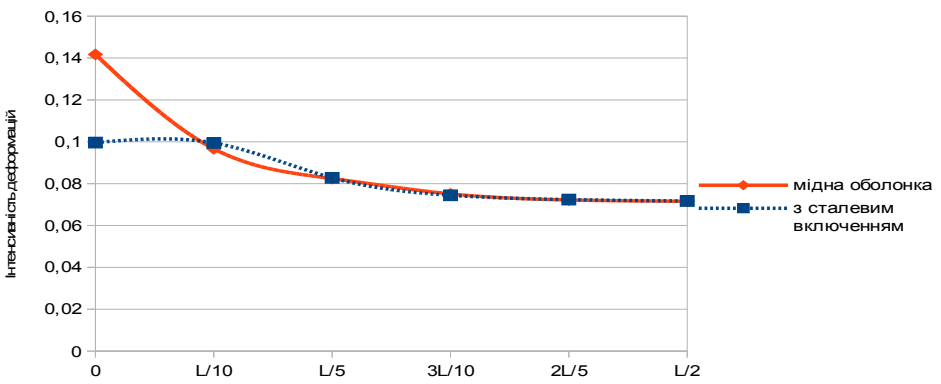

Рис. 5 - Розподіл інтенсивності деформацій $\varepsilon_{i}$ вздовж меридіана оболонки 3 круговим отвором та тонким кільцевим включенням при $k>1$

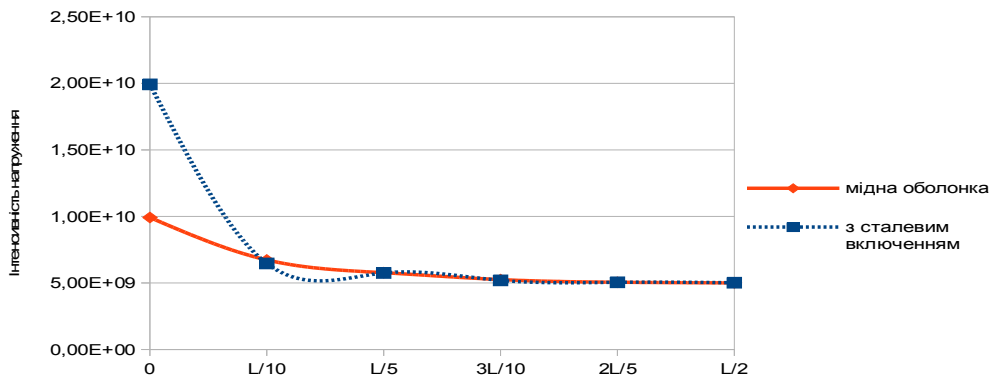

Рис. 6 - Розподіл інтенсивності напружень $\sigma_{i}($ Па) вздовж меридіана оболонки 3 круговим отвором та тонким кільцевим включенням при $k>1$

Розглянемо випадок, коли кільцеве включення має ширину $h_{1} \mathrm{i}$ знаходиться на відстані $h_{1}$ від контуру кругового отвору.

3 рис. 7 та рис. 8 випливає, що застосування "жорсткого» кільцевого включення $(k>1)$ на певної відстані $\left(h_{1}\right)$ від контуру отвору призводить до зменшення інтенсивності напружень на $20 \%$ у порівнянні з випадком для оболонки без включень. Тут, на відміну від випадку безпосереднього підкріплення контуру отвору, має місце також зменшення інтенсивності деформацій. Зменшення відбувається на 20\%.

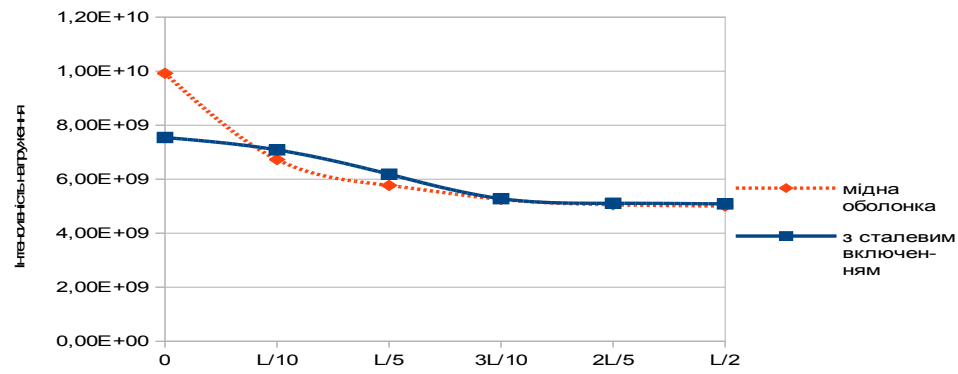

Рис. 7 - Розподіл інтенсивності напружень $\sigma_{i}($ Па) вздовж меридіана оболонки 3 круговим отвором та кільцевим включенням на відстані $h_{1}$ при $k>1$ 


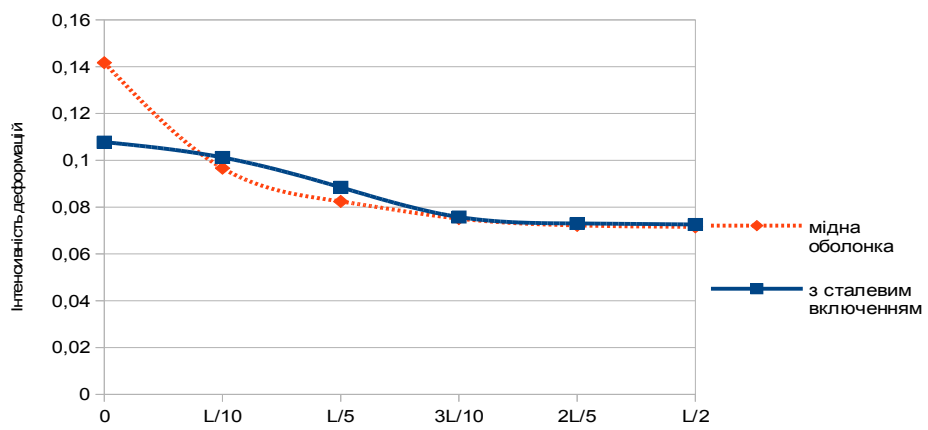

Рис. 8 - Розподіл інтенсивності деформацій $\varepsilon_{\mathrm{i}}$ вздовж меридіана оболонки 3 круговим отвором та кільцевим включенням на відстані $h_{1}$ при k>1

Використання кільцевого включення шириною $h_{1}$, більш «м'якого», ніж матеріал оболонки, розташованого на відстані $h_{1}$ від отвору, призводить до збільшення інтенсивностей напружень і деформацій на $~ 10 \%$ у порівнянні 3 випадком для оболонки без включень. На рис. 9 та рис. 10 проілюстровано розподіл інтенсивностей $\sigma_{i}$ і $\varepsilon_{i}$ відповідно.

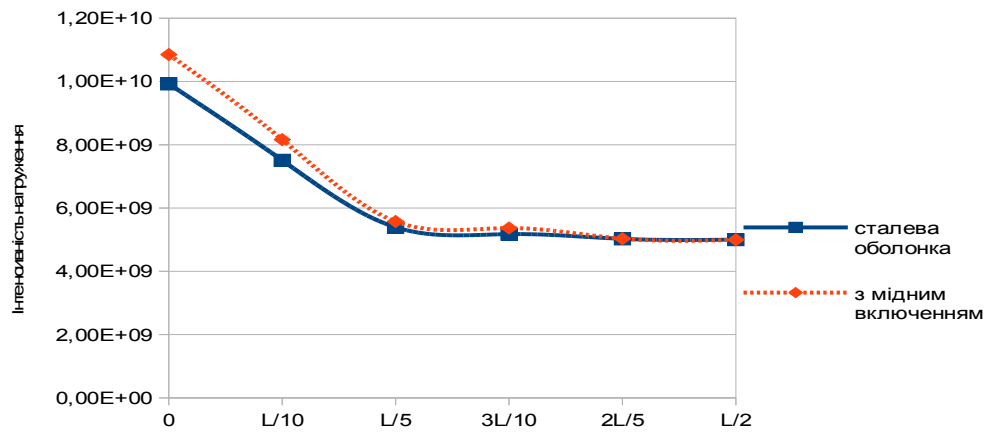

Рис. 9 - Розподіл інтенсивності напружень $\sigma_{i}($ Па) вздовж меридіана оболонки 3 круговим отвором та кільцевим включенням на відстані $h_{1}$ при $k<1$

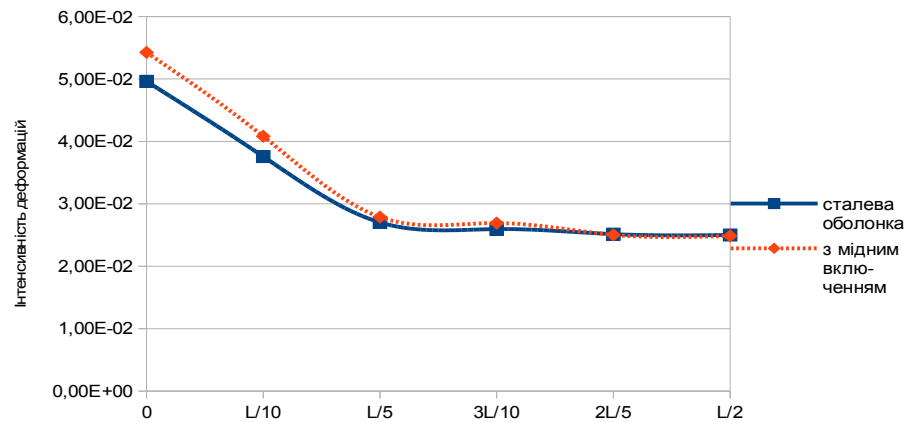

Рис. 10 - Розподіл інтенсивності деформацій $\varepsilon_{i}$ вздовж меридіана оболонки 3 круговим отвором та кільцевим включенням на відстані $h_{1}$ при $k<1$ 
Отже, у випадку моделювання підкріплення тонким пружним кільцевим включенням, розташованим безпосередньо по контуру отвору, при k<1 спостерігається зменшення інтенсивності напружень в $\sim 2,5$ разів, але збільшення інтенсивності деформацій на $20 \%$. При k>1 інтенсивність напружень збільшується в 2 рази, а інтенсивність деформацій зменшується на $25 \%$.

Якщо застосувати кільцеві включення на певній відстані від контуру отвору, то при $\mathrm{k}<1$ інтенсивності напружень і деформацій зростають на $\sim 10 \%$; при k>1 вони зменшуються на $\sim 20 \%$.

Встановлено, що збільшення розміру отвору в сфреричній оболонці, що знаходиться під рівномірним внутрішнім тиском, не впливає на величину коефріцієнта концентрації напружень, але від радіусу отвору залежить величина зони спадання інтенсивності напружень від максимального значення, яке розподіляється рівномірно по контуру отвору, до номінального на периферії оболонки. Збільшення довжини зони переходу вздовж меридіану оболонки знаходиться в прямій пропорційній залежності від збільшення розміру отвору з похибкою $3 \%-5 \%$.

Висновки. На основі проведеного комп'ютерного моделювання та скінченно-елементного аналізу НДС тонкостінної сфреричної оболонки 3 круговим отвором, підкріпленим безпосередньо вздовж його контуру, та на певній відстані від нього кільцевим включенням з іншого матеріалу, отримано розподіл інтенсивностей напружень і деформацій в зонах локальних концентраторів. Встановлено, що при підкріпленні контуру отвору доцільно використовувати кільцеві включення із більш «жорсткого» матеріалу, ніж матеріал оболонки, і розташовувати їх на певній відстані від отвору, що дозволяє зменшити одночасно інтенсивності напружень і деформацій.

\section{БІБЛІОГРАФІЧНІ ПОСИЛАННЯ}

1. Абовский Н. П., Андреев Н. П. , Деруга А. П. Вариационные принципы теории упругости и теории оболочек. М.: Наука, 1978. 228 с.

2. Авдонин А. С., Фигуровский В. Ф. Расчет на прочность летательных аппаратов. М.: Машиностроение, 1985. 439 с.

3. Арзамасов Б. Н., Соловьева Т. В. , Герасимов С. А. Справочник по конструкционным материалам. М.: Изд-во МГТУ им. Н. Э. Баумана, 2005. 640 с.

4. Гарт Е. Л., Василевський К. О. Комп'ютерне моделювання поведінки пологої оболонки з круговими отворами при розтягу // Проблеми обчислювальної механіки і міцності конструкцій: зб. наук. праць. Д.: Ліра, 2014. Вип. 22. С. 57-66.

5. Гарт Э. Л., Панченко С. В. Численный анализ напряжённо-деформированного состояния пластины с прямоугольным отверстием, подкреплённым треугольными накладками // Проблеми обчислювальної механіки і міцності конструкцій: зб. наук. праць. Д.: Ліра, 2015. Вип. 24. С. 35-47.

6. Гудрамович В. С., Гарт Е. Л., Марченко О. А. Вплив форми підкріплень на напружено-деформований стан циліндричної оболонки з видовженими прямокутними 
отворами // Проблеми обчислювальної механіки і міцності конструкцій: зб. наук. праць. - Д.: Ліра, 2017. Вип. 27. С. 52-64.

7. Гудрамович В. С., Гарт Е. Л., Панченко С. В. Напружено-деформований стан пластин з підкріпленими прямокутними отворами різної орієнтації відносно напрямку дії зусилля розтягу // Техническая механика. 2018. №4. С. 82-89.

8. Гузь А. Н., Чернышенко И. С., Чехов Вал. Н. , Чехов Вик. Н., Шнеренко К. И. Методы расчета оболочек. В 5 т. Т. 1. Теория оболочек, ослабленных отверстиями. К. : Наукова думка, 1980. 636 с.

9. Довбня Е. Н., Крупко Н. А. Влияние кругового отверстия на напряженное состояние оболочки произвольной гауссовой кривизны // Вісник Донец. ун-ту. 2004. Вип. 1. С. $108-125$.

10. Закора С. В., Чехов В. Н., Шнеренко К. И. О концентрации напряжений около кругового отверстия В трансверсально-изотропной сферической оболочке // Прикладная механика. 2004. Т. 40. № 12. С.99-106.

11. Именитов Л. Б. Задача о сферической оболочке с неподкрепленным отверстием // Инженерный журнал. 1963. Т. 3. №1. С. 93-100.

12. Погорелов В. И. Строительная механика тонкостенных конструкций. СПб.: БХВ-Петербург, 2007. 528 с.

13. Савин Г. Н. Распределение напряжений около отверстий. К.: Наукова думка, 1968. $888 \mathrm{c}$.

14. Сахаров А. С. Альтенбах И. Метод конечных элементов в механике твердых тел. К.: Высш. шк., 1982. 480 с.

15. Сегерлинд Л. Применение метода конечных элементов. М.: Мир, 1979. 392 с.

16. Сяський А. А., Лунь Е. И. Напряженное состояние изотропной сферической оболочки с круговым отверстием // Прикладная механика. 1974. Т.10. № 8. С. 98-102.

17. Чехов В.Н., Закора С. В. Концентрация напряжений в сферической оболочке с двумя близко расположенными круговыми отверстиями // Мат. методы и физ.-мех. поля. 2010. Т. 53. № 3. С. 93-98.

18. Шевляков Ю. А. Напряжение в сферическом днище, ослабленном круговым вырезом // Инж. сб. М.: Наука, 1956. Вып. 24. С.226-230.

19. Gudramovich V. S., Gart É. L., Strunin K. A. Modeling of the behavior of planedeformable elastic media with elongated elliptic and rectangular inclusions // Materials Science. 2017. Vol. 52. Iss. 6. P. 768-774.

20. Hart E. L., Hudramovich V. S., Ryabokon'S. A., Samarskaya E. V. Numerical simulation of stress-strain state for nonhomogeneous shell-type structures based on the finite element method // J. Modeling and Numerical Simulation of Mater. Sci. 2013. Vol. 3. No. 4. P. 155-157.

21. Hart E. L., Hudramovich V. S. Application of the projection-iterative scheme of the method of local variations to solving stability problems for thin-walled shell structures under localized actions // Strength of Materials. 2018. Vol. 50. Iss. 6. P. 852-858.

22. Hudramovych V. S. Features of nonlinear deformation and critical states of shell systems with geometrical imperfections // Int. Appl. Mech. 2006. Vol. 42. No. 12.. P. 1323-1355.

23. Maksim'uk V. A., Storozhuk E. A., Chernyshenko I. S. Varitional-difference methods in linear and nonlinear problems of deformation of the shells from metallic and composite materials // Int. Appl. Mech. 2012. Vol. 48. No. 6. P. 613-687.

24. Zienkiewicz O. C., Taylor R. L. The finite element method for solid and structural mechanics. New York: Elsevier, 2005. 632 p. 
Э. Л. Гарт, д-р фоиз.-мат. наук,

В. С. Гудрамович, чл.-корр. НАН Украины, д-р техн. наук,

О. А. Марченко

\section{ВЛИЯНИЕ КОЛЬЦЕВОГО ВКЛЮЧЕНИЯ \\ НА НАПРЯЖЕННО-ДЕФОРМИРОВАННОЕ СОСТОЯНИЕ СФЕРИЧЕСКОЙ ОБОЛОЧКИ С КРУГОВЫМ ОТВЕРСТИЕМ ПРИ ДЕЙСТВИИ РАВНОМЕРНОГО ВНУТРЕННЕГО ДАВЛЕНИЯ}

Проведено компьютерное моделирование напряженно-деформированного состояния тонкостенной сферической оболочки с круговым отверстием, подкрепленным кольцевым включением из другого материала, находящейся под действием равномерного внутреннего давления. Исследовано влияние геометрических и механических параметров включений на процесс десормирования оболочки.

Ключевые слова: сферическая оболочка, круговое отверстие, кольцевые включения, внутреннее давление, напряженно-деформированное состояние, коэффрициент концентрации напряжений, метод конечных элементов.

UDC 539.3

E. L. Hart, Dr. Sci. (Phys.-Math.),

V. S. Hudramovich, Corresponding member of NAS Ukraine, Dr. Sci. (Tech.), O. A. Marchenko

\section{INFLUENCE OF ANNULAR INCLUSION ON THE STRESS-STRAIN STATE OF A SPHERICAL SHELL WITH A CIRCULAR HOLE WITH ACTION OF UNIFORM INTERNAL PRESSURE}

A computer simulation of the stress-strain state of a thin-walled spherical shell with a circular hole, supported by an annular inclusion of another material under uniform internal pressure, was carried out. The influence of geometrical and mechanical parameters of inclusions on the process of shell deformation is investigated.

Keywords: spherical shell, circular hole, annular inclusions, internal pressure, stress-strain state, stress concentration factor, finite element method.

Thin-walled spatial structures, elements of which are shells, are widely used in various fields of technology, industry, energy, etc. [1-4, 12, 22, 23]. Basing on various structural or technological considerations, holes and openings in shells are often fulfilled, that create local stress concentrators. They can adversely affect the process of operating the structure, leading to its premature failure $[9,10,17]$.

One of the solutions to this issue is the use of reinforcements or inclusions around holes, various geometric shapes and mechanical properties [5-7, 19]. This, in turn, leads to an increase in the complexity of the mathematical model of the problem. To study the stress-strain state of structures with inhomogeneities (holes, inclusions, etc.) it is advisable to use 
numerical methods of mechanics, which, unlike analytical methods, are quite universal. The most effective include: the finite element method [14, 15, 24], the finite difference method, etc., and their projection-iterative implementation schemes $[20,21]$, which can significantly reduce the time expenses of computer calculations.

In this work, a computer simulation of the behavior of a thin-walled spherical shell with a circular hole and an annular inclusion was carried out and a finite element analysis was made of the influence of the geometrical and mechanical parameters of the reinforcing elements of the circular hole on its stress-strain state.

Conclusions. On the basis of the finite-element simulation of the stressstrain state of a spherical shell with a circular hole with reinforcement, in the form of an annular inclusion, the distribution of the intensity of stresses and deformations in the zones of the shell local concentrators is obtained. In the case of simulation of reinforcement directly into the outline of the hole, at $\mathrm{k}<1$ ( $\mathrm{k}$ - relative rigidity of inclusion, $k=E_{\text {incl }} / E_{\text {sh }}$, where $E_{\text {incl }}$ is the modulus of elasticity of inclusion; $E_{s h}$ is the elastic modulus of the shell) there was a decrease in the intensity of the stress by $\sim 2.5$ times, but at the same time the increase in the intensity of the deformation by $\sim 20 \%$. At $k>1$ the intensity of the stresses is increased by $\sim 2$ times, and the intensity of the deformations decreases of $\sim 25 \%$. If you apply inclusions at a distance from the contour of the hole, then at $k<1$ the intensities of stress and deformation increase of $\sim 10 \%$. Using $k>1$, the intensities decrease of $\sim 20 \%$. Thus, when reinforcing the outline of the hole, it is expedient to use the inclusion of a more "rigid», since it leads to a decrease in the intensity of deformation, as well as when reinforced at a distance. The use of a more «soft» inclusion at a distance is inappropriate, since this type of reinforcement leads to an increase in the intensity of stress and strain.

\section{REFERENCES}

1. Abovskii N. P., AndreevN. P., Deruga A. P. Variational principles of the theory of elasticity and the theory of shells. Moscow: Nauka, 1978. 228 p. (in Russian).

2. Avdonin A. S. Figurovskii V. F. Calculation of strength for aircrafts. Moscow: Mashinostrojenie, 1985. 439 p. (in Russian).

3. Arzamasov B. N., Solovieva T. V., Gerasimov S. A. Handbook of structural materials. Moscow: MSTU them. N. E. Bauman, 2005. 640 p. (in Russian).

4. Hart E. L., Vasilevsky K. A. Computer simulation of the behavior of a shallow shell with circular holes under tension // Problems of Computational Mechanics and Strength of Structures: Col. of sci. art. Dnepropetrovsk: Lira. 2014. Vol. 22. P. 57-66. (in Ukrainian).

5. Hart E. L., Panchenko S. V. Numerical analysis of the stress-stain state of a plate with a rectangular hole, supported by triangular overlays // Problems of Computational Mechanics and Strength of Structures: Col. of sci. art. Dnepropetrovsk: Lira. 2015. Vol. 24. P. 35-47. (in Russian).

6. Hudramovich V. S., Hart E. L., Marchenko A. A. Influence of the shape of reinforcements on the stress-strain state of a cylindrical shell with elongated rectangular holes // Problems of Computational Mechanics and Strength of Structures: Col. of sci. art. Dnipro: Lira. 2017. Vol. 27. P. 52-64. (in Ukrainian).

7. Hudramovich V. S., Hart E. L., Panchenko S. V. The stress-strain state of plates with reinforced rectangular holes of different orientations relative to the direction of action of the tensile force // Technical Mechanics. 2018. №4. P. 82-89. (in Ukrainian). 
8. Guz A. N., Chernyshenko I. S. and etc. Methods for calculating shells. In 5 vol. V. 1. Theory of shells weakened by holes. Kiev: Naukova dumka, 1980. 636 p. (in Russian).

9. Dovbnya E. N., Krupko N. A. Influence of a circular hole on the stressed state of a shell of arbitrary Gaussian curvature // Visnyk Donetsk. un-tu. 2004. Vol.1. P. 108-125. (in Russian).

10. Zakora S. V., Chekhov V. N., Shnerenko K. I. About stress concentration near a circular hole in a transversely isotropic spherical shell // Applied Mechanics. 2004. Vol. 40. No 12. P. 99-106. (in Russian).

11. Imenitov L. B. The problem of a spherical shell with an unsupported hole // Engineering Journal. 1963. Vol. 3. No 1. P. 93-100. (in Russian).

12. Pogorelov V. I. Construction mechanics of thin-walled structures. St. Petersburg: BHV-Petersburg, 2007. 528 p. (in Russian).

13. Savin G. N. Stress distribution around holes. Kiev: Naukova dumka, 1968. 888 p. (in Russian).

14. Sakharov A. S., Altenbach I. The finite element method in the mechanics of solids. Kiev: Vischa shkola, 1982. 480 p. (in Russian).

15. Segerlind L. Applied finite element analysis. Moscow: Mir, 1979. 392 p. (in Russian).

16. Syaskiy A. A., Lun E. I. The stressed state of an isotropic spherical shell with a circular hole // Applied Mechanics. 1974. Vol. 10. No 8. P. 98-102. (in Russian).

17. Chekhov V. N., Zakora S. V. Stress concentration in a spherical shell with two closely spaced circular holes // Matem. metody ta fizyko-mekhan. polya, 2010. Vol. 53. No. 3. P. 93-98. (in Russian).

18. Shevlyakov Yu. A. Tension in a spherical bottom weakened by a circular hole // Engineering collection. Moscow: Nauka. 1956. Vol. 24. P. 226-230. (in Russian).

19. Gudramovich V. S., Gart É. L., Strunin K. A. Modeling of the behavior of planedeformable elastic media with elongated elliptic and rectangular inclusions // Materials Science. 2017. Vol. 52. Iss. 6. P. 768-774.

20. Hart E. L., Hudramovich V. S., Ryabokon'S. A., Samarskaya E. V. Numerical simulation of stress-strain state for nonhomogeneous shell-type structures based on the finite element method // J. Modeling and Numerical Simulation of Mater. Sci. 2013. Vol. 3. No. 4. P. 155-157.

21. Hart E. L., Hudramovich V. S. Application of the projection-iterative scheme of the method of local variations to solving stability problems for thin-walled shell structures under localized actions // Strength of Materials. 2018. Vol. 50. Iss. 6. P. 852-858

22. Hudramovych V. S. Features of nonlinear deformation and critical states of shell systems with geometrical imperfections // Int. Appl. Mech. 2006. Vol. 42. No. 12. P. 13231355.

23. Maksim'uk V. A., Storozhuk E. A., Chernyshenko I. S. Varitional-difference methods in linear and nonlinear problems of deformation of the shells from metallic and composite materials // Int. Appl. Mech. 2012. Vol. 48. No. 6. P. 613-687.

24. Zienkiewicz O. C., Taylor R. L. The finite element method for solid and structural mechanics. New York: Elsevier, 2005. 632 p.

Дніпровський національний університет імені Олеся Гончара, Дніпро, Україна

Надійшла до редколегії 20.03.2019 